\title{
Construction and Research of Innovative and Entrepreneurial Practice Platform for Students of Industrial Design*
}

\author{
Qiulei Du ${ }^{\text {, }}$, Liai Pan ${ }^{b}$ \\ College of Mechanical and Vehicle Engineering, Changchun University, Changchun, Jilin, 130022, \\ China \\ a apriljuan@hotmail.com, b panli636@126.com
}

Keywords: Industry Design ; Innovation and Entrepreneurship ; Practice ; 3D Platform.

\begin{abstract}
In the paper, the construction and measures of innovative and entrepreneurial practice platform for the major of industrial design have been studied, and it have been introduced comprehensively and detailedly how to how to develop their innovative and entrepreneurial abilities. According to the teaching actuality of industrial design, six measures have been presented to construct a 3D platform of innovation and entrepreneurship practice, including: optimizing curriculum system and teaching content, appropriately arranging practice teaching in innovation and entrepreneurship, making production practice play an important role in innovation and entrepreneurship, making computers aided role in innovation and entrepreneurship, constructing training base in innovation and entrepreneurship, and practicing the 3D platform.
\end{abstract}

\section{Introduction}

Learning and application of knowledge and innovation are the source of the existence and development of human society. To cultivate students' innovative, entrepreneurial capacity is a key issue which has been constantly explored by the education sector. Former General Secretary Hu Jintao's important speech on the Tsinghua University Centennial Congress, pointed out: "innovation" has become "a major driving force for economic and social development " and higher education should "put emphasis on training top creative talents and actively create a good environment to encourage independent thinking, free exploration and brave innovation so as to encourage students to vigorously create and become creator of new knowledge, inventors of novel invention and founders of neoteric subjects". It can be seen that it is important for colleges and universities to seriously implement higher education quality improvement project, cultivating students' innovation and entrepreneurship and further promote the key elements of the Higher Education Teaching Reform during the 12th Five-Year. Currently, a number of schools in our country have built or are building innovative experimental teaching system in line with the students' development. ${ }^{[1]}$

\section{Purpose and Significance of the 3D Platform for Innovation and Entrepreneurship}

Industrial design is an emerging subject of science and aesthetics, technology and art, and an intersection complete system unifying artistic, technical, economic multidisciplinary knowledge. Industrial design practice teaching is based on the guidance of the scientific concept of development and the deepening educational reform. Connecting industrial design teaching innovation and entrepreneurship practice is an important part of the demand of teaching and market's connection. The study of 3D platform for innovation and entrepreneurship practice, based on the needs of society and the market, improves the teaching system of industrial design students practice and enables students to learn not basic theoretical knowledge, but abilities to innovate. And the cultivation of the spirit of innovation provides more effective 3D platform to students so as to cultivate integrated applications talents a solid knowledge of the theoretical basis and practical abilities.

* Corresponding author: Liai Pan, panli636@126.com 
Industrial design students have solid theoretical foundation, wide professional knowledge, strong scientific and technological capabilities, and artistic innovation design ability, which make them in line with the innovative experimental teaching system and capable of innovative business practice. Practice has proved that innovation and entrepreneurship practice are just the advantage of industrial design students. However, there still are problems that industrial design students have weak actual practicing ability, making their creative minds not fully manifested through practice research properly and preventing the innovative, entrepreneurial ability to some extent. Therefore, strengthening the connection of theory and practice teaching and focusing on innovation and entrepreneurship practical teaching links may combine theory, practice and quality, and continuously improve the overall quality of students and their innovative ability to make social adaptability and competitiveness. Therefore, the establishment and study of 3D practice platform for industrial design students' innovation and entrepreneurship is necessary and the combination between theoretical innovation and practice will make students find and apply the new knowledge. It is urgent to gain abilities to solve practical problems during the process of continuous innovation and entrepreneurship improvement.

\section{Measures to Construct a 3D Platform for Innovation and Entrepreneurship}

The same with theory teaching, practice teaching is an important part of the university personnel training activities, and is an important and irreplaceable role to cultivate the students' innovative spirit and practical ability to improve the overall quality of students. The innovation and entrepreneurship of college students are important combination of theory and practice education and they are the actual application of the cultural and creative industries or idea projects, which are based on the students' knowledge, conceptual design and the use of divergent thinking and design to meet market demand. Innovation and entrepreneurial activities can not only greatly inspire students 'enthusiasm for learning, but also improve the overall quality of students so as to cultivate their innovative spirit and practical ability.

\section{Optimization of the Curriculum System and Teaching Content}

By using existing school teaching resources to improve professional competency-oriented curriculum system and optimization of cognitive rules, teaching plans will be reasonably set up. Students should not only master the mechanical professional foundation courses, such as mechanical design, mechanical principles, engineering materials and engineering drawing, which are the foundation of applying theoretical teaching content; but also master the foundation courses of art, such as design sketches, design colors, constituting design, industrial design and performance techniques, which are practice-based and the basis of product design; they should also grasp the mechanical and artistic curriculums, such as ergonomics, material molding modeling and electromechanical product design, which let students understand the design concept of human-oriented product clearly in the process of designing. In addition, when the cultivation of students 'creative thinking is taken into account, some more courses should exist, such as the creation science, creative design and so on, to cultivate students' divergent thinking and enhance students' awareness of innovation and thus to build knowledge reserves.

\section{Reasonable arrangements of practice teaching in innovation and entrepreneurship}

General Secretary Hu Jintao has pointed out that "innovating teaching methods, strengthening practice teaching and forming new advantages of training personnel, will cultivate excellent teachers and first-class talents". The purpose of practice teaching is to allow students to apply their theoretical knowledge and increase their practice capabilities for some special courses teaching so as to improve their professionalism. The profession has been committed to research in this area, and achieved certain results. As of innovation and entrepreneurship, the subject will find problems and meet the shortfalls through practice. By analyzing some specific practical project cases, students 'creative 
thinking will be improved and their practical abilities will get trained, which is the initial idea in the project.

\section{Effect of Production Practice on Innovation and Entrepreneurship}

Production internship is also an important part for the industrial design students to learn. The internship is mainly in Changchun First Automobile Works production internship, internship mainly contains the chassis factory gearbox factory chassis factory, and includes chassis branch, gearbox branch, dedicated depot, special castings and body factory and so on. This practice allows students to truly feel the entire production process of a product so as to cultivate their diligent thinking and summary abilities. It also urges students to apply software to model and analyze some typical products to improve practice capacity, and plays as a guidance for innovation, entrepreneurship platform structure to fit the actual demands. ${ }^{[2]}$

\section{Effect of Computers Aid Design on Innovation and Entrepreneurship}

It is an important means to use computers as aids for industrial design students to innovate their designs. One aspect of the project includes computer-aided construction in the innovation and entrepreneurship system, meaning that students should not understand the graphic design software, but the 3D modeling software. The construction of computer virtual technology platform not only makes the product apparent, assures the manufacturability and assembly, but also greatly shortens the product development cycle by 3D simulation modeling. ${ }^{[3]}$

The other aspect of the study is the use of computer-aided Internet platform, which shares the network resources under support of schools, businesses and society so as to get information diversification and provide effective help and guidance for the innovation and entrepreneurship of students.

\section{Construction of Training Base on Innovative Entrepreneurship}

The creation of innovative entrepreneurship training base lets students learn basic theory knowledge as well as exercise their innovation and entrepreneurship skills, and thus their innovative spirit, practical ability and team spirit will be cultivated and the overall quality will be improved. ${ }^{[4,5]}$

(1) The majority of the innovation and entrepreneurship training base is students and the minority is teachers. The purpose of the base is to combine class experiments with practice projects and get basic operability experiment demonstration, validation and integration. Through periodic update experiments and training content, additional disciplinary development linked to new knowledge, content experiment and training projects will come into better effect.

(2) Students may cooperate with elated enterprises and factories and negotiate the projects in the practice of innovation and entrepreneurship training base project. As a result, the students' scientific research results can transformed into actual products to the market, reflecting the values of the students, reflecting the social value of the product so as to motivate more students to participate in the practice of innovation and entrepreneurship and forma virtuous circle.

(3) The implementation of "special scholarships" system of innovation and entrepreneurship should be set up. Only spiritual value is not that enough, it is important as well to give students material rewards. Fruitful research results of students' innovation and entrepreneurship need be given some material rewards to stimulate their enthusiasm and make more students participate in the practice of innovation and entrepreneurship activities.

(4) In the practice of innovation and entrepreneurship, the construction of the faculty need be strengthened. Schools should take any measure to improve the faculty's quality and strengthen their cultivation to make sure that there are strong faculty backings for students to conduct innovative and entrepreneurial practice activities.

\section{Construction of a 3D practice platform}

The so-called "3D" means "all-round" or" at all levels". Students take up full ranges of experiments and training exercises by learning theoretical knowledge. Through introducing the latest innovative 
projects, renovating, expanding and enriching original experiment projects and putting original design into experimental projects, the research and innovation will proceed smoothly.

\section{Conclusion}

The construction and research of innovative and entrepreneurial practice platform connect students' theoretical innovation consciousness with actual practice effectively, so that the students will search for true knowledge in practice and continuously improve their innovation, entrepreneurship and practical abilities in the process of solving practical problems. At the same time, the theoretical and practical knowledge will be quickly transformed into social productive forces, and the social competitiveness of the industrial design students will be improved to meet the market demands for industrial design professionals and thus it will contribute to social economic development.

\section{References}

[1] Brown, III, Ulysses J. Beale, Ruby L et al (2001) PERCEPTIONS OF ENTREPRENEURIAL INTENTIONS \& RISK PROPENSITY: SELF RELIANCE AND SELF EFFICACY IN COLLEGE STUDENTS TO ENCOURAGE KNOWLEDGE. Review of Business Research.Vol. 11 Issue 5, p169-177

[2] Manimala, Mathew J. (1992) Entrepreneurial Heuristics: A Comparison Between High PI (Pioneering-Innovative) and Low PI Ventures. Journal of Business Venturing. Vol. 7 Issue 6, p477, 28p, 7 Charts

[3] Martín-Cruz; Natalia1 et al (2012) Training and its consequences on the innovative capacity of entrepreneurs. International Journal of Entrepreneurship \& Innovation Management. Vol. 15 Issue 3, p235-251.

[4] Yonca Grol, Nuray Atsan(2006) Entrepreneurial characteristics amongst university students: Some insights for entrepreneurship education andtraining in Turkey. Education + Training. Vol. 48 Issue 1, p25-38.

[5] ZHANG Yuping, QIN Huijie, HUANG Zhenbao(2005). On the Practice Teaching System for Undergraduates. RESEARCH AND EXPLORATION IN LABORATORY. Vol.24 Issue 3, p62-65. 